\title{
De beoordelingsopdracht en het axiomatisch voorbehoud
}

\section{H. Baas}

\section{$1 \quad$ Inleiding}

Over het axiomatisch voorbehoud is niet alleen in het verleden, maar ook nog tamelijk recent, gepubliceerd. Deze publikaties zijn vrijwel allemaal verschenen in de voor accountants bekende vakliteratuur, zoals De Accountant en het MAB. Het gevolg hiervin lijkı te zijn dat de discussies hierover zich voomamelijk afspelen tussen accountants.

Ain de uit 1980 daterende aanbeveling van de Werkgroep Dynamische Functie-analyse om via een meningsuiting met name het maatschappelijk verkeer voor te lichten over dit voor hen en wellicht ook voor accountants zo onbekende onderwerp, is dientengevolge tot op heden slechts gedeeltelijk uitvoering gegeven.

In de (ontwerp) Richtlijnen voor de Accountantscontrole nummer 2.01.1 en 3.01 is weliswar aandacht aan dit onderwerp besteed, onder meer in de vorm van een definitie van het axiomatisch voorbehoud. echter de indruk bestaat dat deze richtlijnen toch meer voor accountants zijn bedoeld dan voor het publiek. In ieder geval zal gelden dat deze richtlijnen meer door accountants dan door andere belanghebbenden worden gelezen.

Daarbij komt nog dal deze richtlijnen zullen worden vervangen door de in het Nederlands te vertalen IFAC richtlijnen. In deze laatste wordt het axiomatisch voorbehoud echter niet expliciet toegelicht. Voor accountants zal vrijwel zeker gelden dat zij onderkennen dat het axiomatisch voorbehoud is begrepen in het in die Richtlijnen gehanteerde begrip 'reasonable assurance'. Of dit echter ook voor het publiek geldt lijkt twijfelachtig.

Het begint er aldus op te lijken dat de door de genoemde Werkgroep gedane aanbeveling. om in ieder geval in de reglementen expliciet aandacht aan het axiomatisch voorbehoud te besteden, geen gevolg zal worden gegeven.

Dat zou zijn te betreuren. immers uit alle discussies over verwachtingskloven etc. kan toch geen andere conclusie worden getrokken dan dat het publiek het begrip axiomatisch voorbehoud onvoldoende kent, laat staan de inhoud ervan begrijpt.

Inmiddels zijn aan de 'officiële accountantsprodukten' onder meer de samenstelling-en beoordelingsopdracht toegevoegd. Bovendien is de kring van wettelijk erkende controleurs van jaarrekeningen uitgebreid met de Accountants Administratie Consulenten, die als wettelijk controleur zijn ingeschreven.

Harmonisatie van de Gedrags- en Beroepsregels en de daarop gebaseerde richtijnen, zoals die galan gelden voor beide groepen accountants zal dienen plaats te hebben en is inmiddels reeds ten dele gerealiseerd. Dit zal dientengevolge eveneens dienen te geschieden voor de reglementering van de hiervoor genoemde nieuwe accountantsprodukten. Ook hiermede is inmiddels een begin gemalakt.

Bij deze voor de beide beroepsgroepen als tamelijk nieuw aan te merken 'produkten' speelt het axiomatisch voorbehoud ook een rol. Zoals hiervoor reeds aangegeven is over dit voorbehoud.

$H$. Baas is vennoot van Deloitte \& Touche, daarnaast verbonden aan de Erasmus Universiteit als wetenschappeiijk onderzoeker. Hij heeft vele vaktechnische functies bij het NIVRA vervuld, waaronder lid van het CBS. 
zoals dat geldt voor controle-opdrachten, redelijk veel valkliteratuur beschikbair. Dit geldı evenwel niet voor dit voorbehoud in relatie tot genoemde nicuwe produkten.

In dit artikel zal alandacht worden besteed aan het axiomatisch voorbchoud zoals dal zou kunnen gelden, dan wel dient te gelden voor de beoordelingsopdracht. In hoofdstuk twee zall allereers alindachl atan de inhoud en betekenis van het axiomatisch voorbehoud worden gegeven. In hooldstuk drie zal een korte bespreking platushebben van de beoordelingsopdracht. walima in hoofdstuk vier zal worden nagegaan op welke wijge het axiomaltisch voorbehoud een plaats dient te krijgen in de beoordelingsopdracht. Het artikel zal worden afgesloten met een samenvatting. waarin tevens zal worden getracht enige conclusies te trekken.

\section{Het axiomatisch voorbehoud}

\section{I Algemeen}

Thet is ranzelfsprekend dat de accoumtant niet verantwerdelijk gehouden kan worden voor een onjuiste of onvolledige vaststelling van voor de jaurekening relevante feiten. indien de iniste of rolledige raststelling slechts uitvoerbat is met ondereockster hmieken waarover de accoumlam mier kan heschikke'n. Dit is het zogenaamde aviomatisch worbehoud".

Aldus de tweede volzin van hoofdstuk V parigraat 3.5 van hel in juni 1980 gepubliceerde discussierapport 'Neutraal, maar niet passief'. In paragrataf 4.2 van datzellde hooldstuk wordt omtrent dit voorbehoud verder nog opgemerki:

'De (geringe) onbetroumbatarheid die aan steckproeven inherent is moet dus a amaard worden. Ook dit is een aspeed ran het aviomatisch voorbehoud: de kastemerhoudingen leiden tor het nement ran steckproeven. wararbij de kleine kans bestant dat onjuistheden ran betekenis ook bij een correcte wirroering ran de steckprocien onontdekt blijeen. Dit gedd eveneens roor fiande'.

In de (ontwerp) Richtlijnen voor de Accountantscontrole 2.01.1 en 3.(0) is het axiomatisch voorbehoud als volgt gedelinieerd:
'Het axiomatisch vorbehoud heeft berrekking op de beperkingen die inherent zijn aan de mogelijkheden van accountantscontrole op grond ran het-ij de aard ran de mogelijke tekorthomingen in de rerantwoording. hetzij het gerechtuaradigde gebrek an deskundigheid ran de areonmtant, dan wel vanwege de maatschappelijk anmarardhare afu'eging van kosten e'n nut ran de controlewerk-atmineden'.

Aldus enige citaten walaruit blijkt wataruit het axiomatisch voorbehoud bestaat en watarop het botrekking heeft.

Terzijde wordt opgemerkt dat het axiomatisch voorbehoud deel uitmakh van iedere accountantsverklaring. dus ongeacht de strekking diarvan. In het vervolg zal echter de nadruk liggen op hel axiomatisch voorbehoud begrepen in de goedkeurende accountantsverklaring. Hetgeen daromtrent wordt opgemerkt is evenwel mutatis mutandis eveneens van toepassing op de andere dan goedkeurende accountantsverklilringen.

\subsection{Kwalitatic en kwantitatief aviomatisch roorbehoud}

In de literaltuur wordt onderscheid gemaakt ussen het kwalitatief en het kwantitatief axiomattisch voorbehoud.

Onder het kwalitatief axiomatisch voorbehoud wordt verstalan de onmogelijkheid van de accountant om bepaalde tekortkomingen in de verantwoording vast te stellen op grond van de natuurlijke grenzen van de accountintscontrole. Deze natuurlijke grenzen bestaan uit het gerechtvaardigde gebrek aan deskundigheid van de accountant voor het ontdekken van bepaialde tekortkomingen en uit de onmogelijkheid van de accountant om voortdurend alanwezig te zijn bij de te controleren huishouding.

Beroep op het $k$ walliatiof axiomatisch voorbe houd is uitsluitend mogelijk indien de accountant heeft vastgesteld dat er bij de gecontroleerde huishouding geen voor accountantscontrole essentiële gebreken bestain in de onvervanghare interne controle en door de accountant bovendien is vastgesteld dat de als toereikend aangemerkite onvervangbare interne controle gedurende de voor de controle relevante periode adequaat heeft gewerkt. 
De wijze waarop de accountant de opzet, het bestaan en de goede werking van de onvervangbare interne controle dient vast te stellen wordt in dit artikel niet nader toegelicht.

Het kwantitatief axiomatisch voorbehoud houdt in dat de accountant niet verantwoordelijk kan worden gehouden voor achteraf blijkende tekortkomingen in de door hem goedgekeurde verantwoording, mits deze tekortkomingen bij een vaktechnisch verantwoord uitgevoerde afweging van kosten en nut van een overigens goed opgezette en uitgevoerde controle, niet ontdekt hadden behoeven te worden.

Het meest aansprekende voorbeeld hiervan is het risico dat blijft bestaan op een onjuiste conclusie als uitkomst van een vaktechnisch juist opgezette en uitgevoerde al dan niet mathematische steekproefcontrole. Overigens ook bij de toepassing van andere controlemiddelen zoals cijferanalyses, zal de accountant bedoelde afweging van kosten en nut maken en kan dus het kwantitatief axiomatisch voorbehoud eveneens een rol spelen.

Terzijde wordt opgemerkt dat in de goedkeurende accountantsverklaring eveneens een zekere mate van (on)nauwkeurigheid is begrepen. Met deze (on)nauwkeurigheid wordt de mate van exactheid van het oordeel bedoeld.

In het maatschappelijke verkeer en in het accountantsberoep is de opvatting geaccepteerd dat absolute nauwkeurigheid van een verantwoording en dus van de controle daarvan, niet noodzakelijk is, omdat er geen verschil bestaat tussen de 'informatie-waarde' van een absoluut nauwkeurige verantwoording en een verantwoording met een hoge mate van nauwkeurigheid en dus een kleine mate van onnauwkeurigheid. In de accountantsverklaring wordt dit tot uitdrukking gebracht door het gebruik van de woorden 'getrouw beeld'.

Dit betekent dat, anders dan wellicht uit het voorgaande en uit de term kwantitatief axiomatisch voorbehoud zou kunnen worden geconcludeerd. het kwantitatief axiomatisch voorbehoud geen betrekking heeft op de (on)nauwkeurigheid van het oordeel, maar uitsluitend op de (on)betrouwbaarheid. Immers de in het oordeel van de accountant begrepen (on)nauwkeurigheid wordt geacht voor alle belanghebbenden bij de controle acceptabel te zijn. Indien zou blijken dal de accountant een te grote onnauwkeurigheid heeft geaccepteerd, kan daarom door hem nooit een beroep op het axiomatisch voorbehoud worden gemaakt, maar kan de conclusie geen andere zijn, dan dat hij een beroepsfout heeft gemaakt.

Het kwantitatief axiomatisch voorbehoud heeft dus evenals het kwalitatief axiomatisch voorbehoud uitsluitend betrekking op de (on)betrouwbaarheid van het oordeel van de accountant.

Kortweg gezegd komt het voorgaande erop neer dat indien de accountant alles heeft gedaan wat een redelijk vakbekwame accountant behoort te doen en de controle geen materiële onjuistheden aan het licht heeft gebracht. de accountant een goedkeurende verklaring bij de door hem gecontroleerde verantwoording kan afgeven.

\section{De beoordelingsopdracht}

\subsection{Voorschriften etc. met betrekking tot de beoordelingsopdracht}

In met name de Angelsaksische landen is een aantal jaren geleden aan de gereglementeerde 'accountantsprodukten' een aantal nieuwe toegevoegd, gezamenlijk aangeduid als audit related services. Dit voorbeeld is daarna gevolgd door de IFAC. Gezien de 'verplichtingen' van het Nederlandse accountantsberoep tegenover de IFAC, diende deze ontwikkeling te leiden tot de implementatie van deze produkten in de regelgeving in ons land.

Daarenboven is te signaleren dat sinds een aantal jaren door de als openbaar accountant optredende registeraccountants concurrentie wordt ondervonden van de door de Accountants Administratie Consulenten specialal ten behoeve van het MKB nieuw ontwikkelde produkten.

Aangezien door de als accountant optredende registeraccountants ook redelijk veel cliënten werkzaam in het MKB worden bediend, was het een gezamenlijk belang van deze accountants dat door het NIVRA een antwoord werd gegeven op de door de AA ontwikkelde produkten.

Het NIVRA zag zich als gevolg van beide ontwikkelingen dientengevolge genoodzaakt niet achter te blijven en heeft aan de door hem gereglementeerde produkten vervolgens de audit related services toegevoegd.

In dat kader is in juni 199/ door het NIVRA de 
Richtlijn voor Accountantscontrole 6.02 gepubliceerd, getiteld 'Beoordeling van Jaarrekeningen'.

In paraglaaf 2 van deze Richtlijn is de volgende omschrijving van de beoordeling van een jaarrekening opgenomen:

Een onderzoek van een accolmtant met betrekking tot een jaarrekening dat erop is gericht om aan de gebruiker ran het beoordelingsrapport een beperkte mate ran zekerheid te verschaffen omtrent de getrouwheid van de jaarrekening, welke mate van zekerheid evenwel lager is dan bij een comrole-opdracht.

Als toepassingsgebied van de beoordelingsopdracht wordt in de Richtlijn aangegeven de situatie:

'waar een onafhankelijk e'll deskundig oordeel gewenst is over de getrouwheid van een jaarrekening, waarbij men echter geen behoefte heeft aan de hoge mate van zekerheid die voortyloeit uit een controle-opdracht'.

Bij de totstandkoming eind 1994 van de voor registeraccountants en Accountants-Administratieconsulenten gelijkluidende Gedrags- en Beroepsregels zijn deze audit related services expliciet in de regelgeving opgenomen. In artikel 1 van de nieuwe GBR is als definitie van een beoordelingsverklaring vermeld:

'Een schriftelijke mededeling van een accountant inhoudende de uitkomst van de beoordeling van een verantwoording'.

terwijl als definitie van beoordeling is vermeld:

'Het geheel lan werkzaamheden dat erop gericht is cen bepaalde mate van zekerheid te verkrijgen omtrent de getronwheid van een verantwoording, welke mate van zekerheid lager is dan bij een controle.'

Uit het voorgaande blijkt dat het verschil ussen een controle-opdracht en een beoordelingsopdracht bestaat uit de mate van zekerheid van het accountantsoordeel omtrent de getrouwheid van de gecontroleerde, respectievelijk beoordeelde verantwoording die kan worden ontleend aan de door de accountant gegeven verklaring. Dit verschil in zekerheid zal dientengevolge een uitgangspunt dienen te zijn bij de bepaling van de aard en omvang van de in de verschillende opdrachten uit te voeren werkzaamheden.

Hieruit kan worden geconcludeerd dat beide opdrachten niet van elkaar verschillen ten aanzien van de (on)nauwkeurigheid die bij de planning en uitvoering van de verschillende opdrachten in acht dient te worden genomen en dat dientengevolge de (on)nauwkeurigheid van de verklaring van de accountant bij beide opdrachten niet van elkaar verschilt.

Aan de beoordelingsopdracht is in de accountantsliteratuur zeer veel aandacht besteed. waarbij zowel voor-als tegenstanders uitvoerig de vooren nadelen ervan hebben uiteengezet. In dit artikel zal hieraan verder geen uitgebreide aandacht worden geschonken, doch zal worden uitgegaan van het gegeven dat de beoordelingsopdracht inmiddels tot de gereglementeerde 'accountantsprodukten` behoort.

In genoemde Richtlijn is aangegeven welke werkzaamheden bij de uitvoering van een beoordelingsrapport dienen te worden uitgevoerd, namelijk die werkzaamheden die de accountant:

'noodzakelijk acht om een uitspraak te doen omtrent de rraag of hem iets is gebleken op grond warvan hij zou moeten concluderen dat de jaarrekening niet voldoet aan de in paragraaf I gestelde eisen'.

In paragraaf I wordt met betrekking tot deze eisen vermeld:

'Alsdan kan de accountant een beoordelingsopdracht aanvaarden, die welis war een lagere mate van zekerheid verschaft, doch waarbij hij niettemin toetst of de financiële informatie getrouw is weergegeven in overeenstemming met de van toepassing zijnde grondslagen en bepalingen'.

Duidelijke eisen lijken dit niet. Daarbij komt nog dat die onduidelijkheden feitelijk nog groter zijn. immers bedacht dient te worden dat naarmate door de accountant minder werkzaamheden worden uitgevoerd, met des te meer betrouwbaarheid hij de uitspraak kan doen dat hem niets is gebleken op basis waarvan hij zou moeten conclu- 
deren dat de beoordeelde jaarrekening niet voldoet aan de daaraan te stellen eisen.

Deze onduidelijkheden zijn vanzelfsprekend ook door het NIVRA geconstateerd. De hiervoor gekozen terechte oplossing is geweest het voorschrijven van een minimum programma. dat te allen tijde dient te worden uitgevoerd en het overigens niet nader geconcretiseerde voorschrift dat de accountant, naast deze verplichte werkzaamheden, vast dient te stellen welke beoordelingsprocedures in de gegeven situatie daarenboven moeten worden toegepast. Daarbij dient hij met een aantal in de Richtlijn met name genoemde omslandigheden rekening te houden.

Tevens is voorgeschreven dat indien de accountant bij de uitvoering van zijn van te voren vastgestelde werkprogramma op vragen stuit ten aanzien van de volledigheid of juistheid van de in de jaarrekening verstrekte informatie. door hem die aanvullende werkzaamheden dienen te worden verricht. die hij nodig acht om hem alsnog in staat te stellen de gewenste (dus beperkte) zekerheid te verkrijgen, of om vast te stellen of en zo ja, welke aanpassing van de conclusie in zijn verklaring vereist is.

\subsection{De mate van zekerheid van een goedkeurende beoordelingsierklaring}

Uit de hiervoor opgenomen beperkte behandeling van de beoordelingsopdracht kan worden geconcludeerd dat het doel van een beoordelingsopdracht is het aan de gebruiker verstrekken van een beperkte mate van zekerheid dat in de beoordeelde verantwoording geen materiële fouten voorkomen. Uit de 'goedkeurende' beoordelingsverklaring van de accountant blijkt evenwel niet de gekwantificeerde omvang van de beperkte mate van zekerheid.

Accountantsverklaringen verstrekken een hoge mate van zekerheid, doch geen absolute. Weliswaar is niet te kwantificeren hoe groot het verschil is tussen de hoge mate van zekerheid en 100\% zekerheid, maar dat dit verschil niet te groot mag zijn is duidelijk, omdat anders de afweging van de hogere kosten van uitgebreidere controle en het toegenomen nut van meer zekerheid op een verkeerde wijze is gemaakt.

Voor beoordelingsopdrachten ligt dit evenwel anders, omdat er een groot verschil bestaat tussen de verstrekte beperkte mate van zekerheid en de absolute $(=100 \%)$ zekerheid. Echter hoe groot dit verschil is blijkt nergens uit en is ook bij de accountant niet bekend. De accountant kent derhalve de omvang van de door hem verstrekte zekerheid niet. De gebruiker van de beoordelingsverklaring kent deze evenmin.

De aan de beoordelingsopdracht impliciet ten grondslag liggende veronderstelling dat de accountant en de gebruiker dezelfde verwachtingen hebben omtrent de hoogte van de door de accountant verstrekte beperkte mate van zekerheid is dus nergens op gebaseerd. Dat dit een belangrijk bezwaar is tegen de beoordelingsopdracht zal duidelijk zijn.

\section{Het axiomatisch voorbehoud en de beoordelingsopdracht}

In de voorgaande hoofdstukken is zowel aandacht besteed aan het axiomatisch voorbehoud, zoals dat geldt voor door accountants uitgevoerde controle-opdrachten, als aan het voor accountants betrekkelijk nieuwe produkt van de beoordelingsopdracht. In deze paragraaf zal aandacht worden besteed aan het axiomatisch voorbehoud zoals dat dient te gelden voor beoordelingsopdrachten.

In hoofdstuk 2 zijn drie aspecten van het axiomatisch voorbehoud, zoals dat van toepassing is op controle-opdrachten, onderscheiden, namelijk:

1 het gerechtvaardigde gebrek aan deskundigheid van de accountant;

2 de onmogelijkheid van de accountant om voortdurend aanwezig te zijn op alle plaatsen waarop zich voor de verantwoording relevante gebeurtenissen voltrekken;

3 de maatschappelijk aanvaardbare afweging van kosten en nut van de controlewerkzaamheden.

Hierna zal worden nagegaan of deze aspecten van het axiomatisch voorbehoud eveneens op de beoordelingsopdracht van toepassing zijn en zo ja. in welke mate.

\section{I Het gerechtraardigde gehrek aan deskundigheid van de accountant}

In hoofdstuk 2 is dit aspect van het axiomatisch voorbehoud besproken.

Het behoeft geen nadere toelichting dat. hetgeen daar is vermeld omtrent dit gerechtvaardigde gebrek aan deskundigheid van de accountant 
in een controle-opdracht, eveneens van toepassing is op de alan de controle verwante beoordelingsopdracht. Gebrek aan commerciële en technische kennis valn de accountant zal ook bij een beoordelingsopdracht als gerechtvalardigd dienen te worden aangemerkt.

Artikel 11 GBR bepaalt dat de accountant slechts mededelingen omtrent de uitkomst van zijn arbeid mag doen voor zover zijn deskundigheid en de door hem verrichte werkzaamheden dalarvoor een deugdelijke grondslag vormen.

Uit deze bepaling volgt dat voor het doen van een mededeling door de accountant tenminste een bepalalde deskundigheid is vereist.

Die deskundigheid is overigens ook vereist om te kunnen voldoen aan de lweede voorwatrde van artikel $1 /$ GBR. De bepaalde deskundigheid is namelijk niet alleen vereist voor het doen van een mededeling. doch is met name vereist voor het bepalen van de aard en de omvang van de in dit artikel bedoelde werkzalamheden. Tussen de vereiste deskundigheid en de verrichte werkziamheden bestaal derhalve een onverbrekelijke relatie.

De vraiag kan dan worden gesteld of er een verschil bestaal Iussen de deskundigheid. andere dan die op commercieel en lechnisch gebied, noodzakelijk voor het verrichten van een controleopdracht en de deskundigheid vereist voor het uitvoeren van een beoordelingsopdrach.

Indien deze vraag bevestigend zou mocten worden beantwoord. betekent dit dat op dit aspect van hel axiomatisch voorbehoud bij beoordelingsopdrachten eerder een beroep zou kunnen worden gedaan dan bij een controle-opdracht.

Hel lijkt op he1 eerste gezicht voor de hand te liggen om te stellen dal de conform artikel 11 GBR vereiste deskundigheid voor de uitvoering van een beoordelingsopdracht van een ander, in casu "lager" niveau is dan de conform artikel 11 GBR vereiste deskundigheid voor de uitvoering valn een controle-opdracht.

Voorwaarde is dan wel dat het zeker is dat de uitvoering van een beoordelingsopdracht voor een accountant "eenvoudiger" is dan de uitvoering van een controle-opdracht. Indien dit inderdatad het geval zou zijn, ligt de conclusie dat voor eenvoudige werkziamheden minder deskundigheid noodzakelijk is din voor moeilijke werkzaanheden. voor de hand. Deze regel geldı immers voor iedere vorm van rationele werkverdeling.

Deze vraiag kan worden beantwoord door het vergelijken valn de normatal in een controleopdracht te verrichten werkzaamheden en het door het NIVRA voorgeschreven minimum programma dat bij een beoordetingsopdracht moet worden uitgevoerd. In hoofdstuk 3 is deze vergelijking gemaakt. Daarbij is gebleken dat de verschillen voornamelijk bestaan uil de bij beoordelingsopdracht niet. dan wel zeer heperkı, uit te voeren controle op de juiste werking van de interne controle en uit de bij beoordelingsopdrachten niet. dan wel zeer beperkt. uit te voeren detailcontroles. Uit deze vergelijking blijkt dat deze verschillen voornamelijk bestaan uit bij beoordelingsopdrachten minder, dan wel in hel geheel niel, voorkomende werkzaamheden die geen speciale deskundigheid van de accountant vereisen.

Hel verschil tussen beide opdrachten zit dus in de bij beoordelingsopdrachten niet, dan wel beperkt. uit te voeren cenvoudige werkzilanheden. Voor de in beide opdrachten wel uit te voeren werkzamheden is evenwel dezelfde hoge deskundigheid vereist.

De conclusie uil het voorgaande dient datarom te luiden dat de van de accountant vereiste deskundigheid. noodzakelijk om een beoordelings- of een controle-opdracht uit te voeren. exact met elkiar overeenkomen. Dat betekent dat het axiomatisch voorbehoud. voor zover dat verband houdt met het gerechtvalardigd gebrek alan deskundigheid. voor beide soorten opdrachlen van dezelfde aard is en dus op controle- en beoordelingsopdrachten in dezelfide mate van toepassing is.

\subsection{De onmogelijkheid ran de acconntant om roortdurend anwe zig te zijn op alle platatse"n watrop zich woor de verantwoording relevante gebeurtenissen voltrekiken.}

Volstrekt duidelijk zal zijn dat indien voor een controle-opdracht geld dat een accountant niet voortdurend aanwezig kan zijn op alle plaatsen walarop zich voor de verantwoording relevante gebeurtenissen voltrekken. dit eveneens voor een beoordelingsopdracht geldt. Echter om hieruit de conclusie te trekken dat dit aspect van het axiomatisch voorbehoud onverkort en in gelijke mate op beide opdrachten van toepassing is, lijkt iets te voorbarig te zijn. Immers indien een bepalalde verantwoording als uitgangspunt wordt genomen en een vergelijking zou worden gemaakt tussen de benodigde tijd voor de uitvoering van een controle of een beoordeling van die verantwoording. dan 
zal blijken dat de uitvoering van een beoordelingsopdracht minder tijd vergt (en dientengevolge ook minder kost) dan een controle-opdracht. De besteding van minder tijd bij een beoordelingsopdracht is mede het gevolg van het bij de uitvoering van een beoordelingsopdracht minder aanwezig zijn van de accountant op die plaatsen waarop zich voor de verantwoording relevante gebeurtenissen voltrekken.

Dit wordt evenwel niet veroorzaakt door de fysieke onmogelijkheid van de accountant om langer en vaker aanwezig te zijn, maar door de aard van de beoordelingsopdracht. De beperkte mate van zekerheid die met de uitvoering van een dergelijke opdracht wordt beoogd, heeft als onvermijdelijke consequentie dat de aard en omvang van de noodzakelijke werkzaamheden voor de uitvoering van een beoordelingsopdracht daaraan zijn aangepast en dat dientengevolge de accountant minder vaak zijn cliënt zal bezoeken.

Dit komt onder meer tot uitdrukking in het in hoofdstuk 3 toegelichte verschil tussen de 'standaard werkprogramma 's' voor zowel controle- als beoordelingsopdrachten. Als een van de belangrijkste verschillen hiertussen is daar genoemd, de bij beoordelingsopdrachten niet en bij controleopdrachten wel uit te voeren controle op de werking van de interne controle.

Deze verschillen in werkzaamheden hebben als gevolg een kortere en vermoedelijk ook minder frequente aanwezigheid van de accountant bij zijn cliënt bij de uitvoering van een beoordelingsopdracht, dan bij de uitvoering van een controleopdracht.

Dat betekent dat bij een beoordelingsopdracht de met de onmogelijkheid van de accountant om voortdurend aanwezig te zijn op alle plaatsen waarop zich voor de verantwoording relevante gebeurtenissen voltrekken, niet bedoeld wordt de fysieke onmogelijkheid, maar de onmogelijkheid die voortvloeit uit de aard van de opdracht. Bij beoordelingsopdrachten is die onmogelijkheid van een grotere omvang dan bij controle-opdrachten.

De conclusie uit het voorgaande is dat dit aspect van het axiomatisch voorbehoud bij een beoordelingsopdracht een ruimere strekking heeft dan bij een controle-opdracht. Hoeveel ruimer is evenwel niet bij voorbaat te zeggen, maar zal in voorkomende gevallen moeten worden bepaald op basis van de beoordeling van de juistheid van het bij een beoordelingsopdracht gehanteerde werkprogramma en van de juistheid van de uitvoering van dat programma. Vast staat in ieder geval dat het door het NIVRA voorgeschreven minimumprogramma moet zijn toegepast.

\subsection{De maatschappelijk aanvaardbare afweging van kosten en nut van de werkzaamheden}

In hoofdstuk 2 is aangegeven dat dit aspect van het axiomatisch voorbehoud bij controle-opdrachten verband houdt met de afweging van de toename van de controlekosten bij uitbreiding van controlewerkzaamheden en het daarmede te verkrijgen extra nut in de vorm van een toename van de met de controle verkregen zekerheid. Deze afweging leidt er vervolgens toe dat, gegeven het feit dat de gebruikers van de accountantsverklaring geen behoefte hebben aan dat 'beetje meer' zekerheid, de daarvoor te maken kosten als verspilling moeten worden aangemerkt en dientengevolge niet moeten worden gemaakt.

De vraag luidt of bij de uitvoering van een beoordelingsopdracht de bedoelde afweging van kosten en nut eveneens een rol speelt, en zo ja in welke mate en in welke vorm. Het antwoord op deze vraag is niet zo eenvoudig te geven. Dit houdt onder meer verband met het probleem van de niet kwantificeerbare beperkte mate (on)zekerheid verbonden aan de beoordelingsverklaring. Bij controle-opdrachten wordt de afweging tussen nut en kosten bepaald door de afweging tussen een maatschappelijk vereiste hoge mate van zekerheid en een door meer werkzaamheden te bereiken maatschappelijk niet noodzakelijke nog hogere mate van zekerheid, gepaard gaande met een derhalve maatschappelijk als verspilling aan te merken stijging van de kosten van de controle.

Bij beoordelingsopdrachten dient deze afweging eveneens te bestaan uit de vergelijking tussen de toename van de kosten bij uitbreiding van de werkzaamheden en de daarmede te bereiken minder beperkte (=hogere) mate van zekerheid. De vergelijking dient dus te worden gemaakt tussen de toegevoegde waarde van de toegenomen zekerheid te ontlenen aan de beoordelingsverklaring, bestaande uit het verschil tussen beperkte en minder beperkte zekerheid en de daarmede verbandhoudende toename van de kosten. 
Het bijzondere van dit probleem is dat de enige die deze afweging lijkt te kunnen maken de accountant is die, gegeven de hem verstrekte beoordelingsopdracht, dient te bepalen waaruit in die specifieke situatie zijn beoordelingswerkzaamheden en dus de te verstrekken zekerheid dienen te bestaan.

Een bijkomend probleem hierbij is dat de reeds genoemde Richtlijn voor de Accountantscontrole 6.02 'Beoordeling van Jaarrekeningen' de accountant, zoals reeds aangegeven, nauwelijks helpt, omdat hierin uitsluitend een minimum-programma is opgenomen, dat afhankelijk van de concrete situatie dient te worden aangepast en indien de bevindingen tijdens de uitvoering daartoe aanleiding geven, dient te worden uitgebreid. Hoe ver die aanpassing en/of uitbreiding dient te gaan wordt evenwel niet aangegeven.

De accountant dient dus voorafgaande aan en tijdens de uitvoering van zijn beoordelingswerkzaamheden de afweging tussen toegenomen nut en toegenomen kosten te maken. Echter indien achteraf blijkt dat de door de accountant als goed beoordeelde verantwoording niet aan de daaraan te stellen eisen voldoet, zal die afweging wederom worden gemaakt, maar nu niet door de accountant, maar door degenen die constateren dat die desbetreffende verantwoording niet voldoet aan de daaraan te stellen eisen. Indien daardoor schade is geleden, zal de afweging tussen nut en kosten welhaast automatisch een andere zijn dan vooraf door de accountant is gemaakt. Als nut zal dan gelden de bij meer verkregen zekerheid (vermoedelijk) voorkomen schade. Deze eventueel te voorkomen schade zal dan worden vergeleken met de bespaarde kosten. Een complicatie hierbij kan nog zijn dat de schade door anderen wordt geleden dan degenen die hebben 'geprofiteerd" van de bespaarde kosten. In beide situaties zal deze afweging in de meeste gevallen zeer snel doorslaan naar de constatering dat de geleden schade en dus bij uitbreiding van de beoordelingswerkzaamheden wellicht voorkomen schade, belangrijk meer bedraagt dan de bespaarde kosten verbandhoudende met de niet plaatsgevonden uitbreiding van de beoordelingswerkzaamheden.

De vraag die dan moet worden beantwoord luidt of de accountant kan aantonen dat hij een vaktechnisch juiste afweging heeft gemaakt en dat dientengevolge door hem geen beroepsfout is gemaakt, maar dat het 'all in the game' en het 'alle waar naar zijn geld' moet gelden en hij dientengevolge met succes kan aantonen dat hij een goede job heeft uitgevoerd en hij dientengevolge een beroep kan doen op het kwantitatief axiomatisch voorbehoud.

Dit laatste lijkt inderdaad mogelijk. Voorwaarde is dan wel dat de afweging van 'bespaarde' kosten ten opzichte van het gebleken 'gemis' aan betrouwbaarheid (achteraf) waarneembaar is gemaakt en dat daarbij zeer duidelijk in aanmerking is genomen de bedoeling van de beoordelingsopdracht. namelijk het verstrekken van een beperkte mate van zekerheid. Deze afweging dient daarom uit het dossier van de accountant te blijken. Ook dient uit dat dossier te blijken op welke wijze de accountant is omgegaan met tijdens de uitvoering van zijn beoordeling opgekomen vragen ten aanzien van de volledigheid of juistheid van de in de jaarrekening verstrekte informatie.

De dossiers zullen dus hiervoor in uiterste instantie duidelijkheid moeten verschaffen. Indien daaruit blijkt dat de bevindingen op vaktechnisch juiste wijze aanleiding hebben gegeven tot een aanpassing van de conclusie in de verklaring van de accountant. moet worden aangenomen dat door de accountant met succes een beroep kan worden gedaan op het axiomatisch voorbehoud. Minder eenvoudig zal dit evenwel zijn indien de opgekomen vragen hebben geleid tot aanvullende werkzaamheden, immers de Richtlijn stelt dat in die situatie de werkzaamheden in een zodanige omvang moeten worden uitgebreid dat de accountant alsnog in staat is de gewenste, overigens nog steeds beperkte zekerheid, te verschaffen. Welke de omvang van deze gewenste, doch nog immer beperkte zekerheid dient te zijn, met andere woorden in welke omvang de werkzaamheden moeten worden uitgebreid, blijkt niet uit de Richtlijn. De vastlegging in het dossier van de accountant zal daarom ook hierover uitsluitsel dienen te geven.

In voorkomende gevallen zullen degenen die moeten oordelen over de juistheid van de door de accountant gemaakte afweging, zich daarvan dienen te overtuigen. Overlegging en vervolgens onderzoek van het dossier zullen hiervoor doorgaans de enige mogelijkheid zijn. Hierbij zal dan moeten blijken dat tenminste het door het NIVRA voorgeschreven minimumprogramma als uitgangspunt is genomen en dat vervolgens dit minimum- 
programma op de juiste wijze is aangepast aan de specifieke situatie en aan de tijdens de uitvoering van de werkzaamheden opgekomen vragen en dat dit programma vervolgens op de juiste wijze is uitgevoerd.

De conclusie uit het voorgaande dient te zijn dat bij beoordelingsopdrachten het aspect van het axiomatisch voorbehoud met betrekking tot de maatschappelijk aanvaardbare afweging van kosten en nut eveneens van toepassing is doch, dat nog meer dan bij controle-opdrachten, deze afweging gemotiveerd uit het dossier dient te blijken. Het verdient daarom aanbeveling dat Richtlijn 6.02 zodanig wordt aangepast, dat hierin wordt opgenomen dat de accountant bedoelde afweging gemotiveerd moet vastleggen in zijn dossier.

\section{Samenvatting en conclusies}

In dit artikel is getracht aan te geven dat het impliciet in iedere accountantsverklaring opgenomen kwalitatief en kwantitatief axiomatisch voorbehoud, eveneens impliciet deel uitmaakt van iedere beoordelingsverklaring.

Met betrekking tot de twee onderscheiden aspecten van het kwalitatief axiomatisch voorbehoud lijkt dit betrekkelijk eenvoudig aan te tonen. Dit geldt evenwel in mindere mate voor het kwantitatief axiomatisch voorbehoud, omdat er geen sprake (b)lijkt te zijn van een maatschappelijk aanvaardbare afweging van de extra kosten bij uitbreiding van de werkzaamheden en het als gevolg daarvan toegenomen nut bestaande uit een minder beperkte mate van onbetrouwbaarheid van de beoordelingsverklaring.

Desondanks moet worden geconcludeerd dat het kwantitatief axiomatisch voorbehoud ook impliciet deel uitmaakt van de beoordelingsverklaring. De bedoelde afweging dient echter zeer expliciet te worden gemaakt. Uitgangspunt hierbij dient te zijn de doelstelling van de beoordelingsopdracht, te weten een onderzoek met betrekking tot een verantwoording met het oogmerk om aan de gebruiker van het beoordelingsrapport een beperkte mate van zekerheid te verschaffen omtrent de getrouwheid van de jaarrekening, welke zekerheid evenwel lager, doch niet gekwantificeerd lager, is dan bij een controle-opdracht. Uit deze doelstelling vloeit voort dat de bedoelde afweging, gegeven de aard van de beoordelingsop- dracht, te allen tijde dient te worden gemaakt.

Echter vanwege de voortdurend blijkende onbekendheid van het publiek omtrent het bestaan en de draagwijdte van het axiomatisch voorbehoud, welke onbekendheid, naar mag worden aangenomen, met de uitbreiding van het aantal gereglementeerde accountantsprodukten, waaronder de beoordelingsopdracht, eerder is toegenomen dan afgenomen, verdient het aanbeveling indien het NIVRA, gezamenlijk met het NOVAA, komt met een voor een breed publiek toegankelijke publikatie, waarin het axiomatisch voorbehoud in al zijn aspecten en voor alle gereglementeerde accountantsprodukten duidelijk wordt gemaakt.

Er bestaat derhalve behoefte aan een technische specificatie van en een gebruiksaanwijzing voor alle gereglementeerde accountantsprodukten. Hieruit zal dan dienen te blijken waaruit de produktaansprakelijkheid van de accountant bestaat.

\section{I T E R A T U U R}

Baas, H., (1990), De beoordelingsopdracht met betrekking tot jaarrekeningen, De Accountant, november.

Boer, H. den, (1990), Richtlijn 3.03 'Verantwoordelijkheid voor en handelwijze bij het ontdekken van onjuistheden in de verantwoording, De Accountant, juli/augustus.

Blokdijk, J.H., (1988), Het axiomatisch voorbehoud en de verantwoordelijkheid voor fraude, $M A B$, april.

Blokdijk, J.H., (1990), Spreek nu, of zwijg voor immer, De Accountant, oktober.

Blokdijk, J.H., (1994), Het 'axiomatisch' voorbehoud, De Accountant, juni.

Gortemaker, J.C.A., (1987), Het axiomatisch voorbehoud en de verantwoordelijkheid voor fraude, MAB, september.

Kampen, L. van, (1987), Het axiomatisch voorbehoud en de verantwoordelijkheid voor fraude, $M A B$, november.

Niekamp, A., (1987), Het axiomatisch voorbehoud en de verantwoordelijkheid voor fraude, MAB, november.

Nivra, (1989), Ontwerp-Richtliin 0.01. Algemeen kader met betrekking tot controle en daaraan verwante opdrachten, september (opgenomen in RADAR Richtlijnen voor de accountantscontrole RC 0.001, Nivra).

Nivra, (1993), Ontwerp-Richtliin 2.01.1, Functie, taak en verantwoordelijkheid van de accountant, juli (opgenomen in RADAR Richtlijnen voor de accountantscontrole RC 2.01.1, Nivra). 
Nivra, (1993), Ontwerp-Richtliin 3.01, Afbakening en inhoud van het onderzoek naar de getrouwheid van een verantwoording, juli (opgenomen in RADAR Richtlijnen voor de accountantscontrole RC 3.01, Nivra).

Nivra, (1993), Ontwerp-Richtlijn 6.01, Algemene beginselen inzake beoordelingsopdrachten, juli (opgenomen in

RADAR Richtlijnen voor de accountantscontrole RC 6.01, Nivra).
Nivra, (1991), Richtliin 6.02, Beoordeling van Jaarrekeningen, juni (opgenomen in RADAR Richtlijnen voor de accountantscontrole RC 6.02 Nivra).

Nivra, Discussie rapport van de Werkgroep Dynamische Functieanalyse, Neutraal, maar niet passief.

K.P.G. Wilschut, (1987), Onbegrip rondom axiomatisch voorbehoud, verantwoording en verwachtingskloof, De Accountant, november. 